\title{
An Investigation into Saudi Students' Knowledge of and Attitudes towards E-resources on BBC Learning English
}

\author{
Khalid Saleh Alzahrani ${ }^{1}$ \\ ${ }^{1}$ Faculty of Education, Taif University, Taif, Saudi Arabia \\ Correspondence: Khalid Saleh Alzahrani, Faculty of Education, Taif University, Taif, Saudi Arabia. E-mail: \\ kz111@hotmail.com
}

Received: June 6, 2017 Accepted: August 6, 2017 Online Published: August 10, 2017

doi: 10.5539/elt.v10n9p108 URL: http://doi.org/10.5539/elt.v10n9p108

\begin{abstract}
The BBC Learning English website has become an important method of learning and studying English as a second language, a resource that enhances the importance of e-learning. The aim of the current research is to find Saudi students' knowledge of and attitude towards e-resources on BBC Learning English. The sample size was 28 participants (17 male and 11 female participants). The knowledge and attitude were assessed based on scales (from a questionnaire) and their outcomes were correlated with each other; the effect of gender, age and reason for learning were also assessed in relation to the knowledge and attitude variables. Using appropriate statistical tests it was found that there is a significant positive relationship between the knowledge of e-resources and the attitude towards them on BBC Learning English. Gender was not found to have an effect on the attitude scale; however age appeared to have a significant effect on the knowledge variable. The reason for learning English was not found to have an effect on the knowledge of e-resources.
\end{abstract}

\section{Introduction}

\subsection{Background and Statement of the Problem}

E-resources on BBC Learning English play a significant role in student communities; they are an important source of information about learning English. Madhusudhan (2010) mentioned that the electronic source is considered an important source of information about learning and it also can be a good substitute for traditional resources because it provides fast access via computers. Okello-Obura and Ikoja-Odongo (2010) found that the advantages of e-resources include "access to a wide range of information, faster access to information, access to current up-to-date information, easier access to information and improvement of academic performance".

Despite the benefits offered by electronic sources, there are many barriers and problems associated with their use. From the students' perspective, MacWhinnie (2003) and Thachill (2008) argued that in some cases students may not have the technical and research skills sufficient to find proper information, leading them to use the information that they find first. Kinengyere (2007) found that "availability of information does not necessarily mean actual use. This means that users are not aware of the availability of such resources, they do not know how to access them, or they do not know what the resources offer"

Based on technical aspects, Okello-Obura (2010) indicated that, "Among the problems identified are: slow internet connectivity, inadequate networked computers, and lack of awareness of most of the e-resources". Therefore, educational institutions and policy makers should accept the responsibility of training students in computer and research skills and overcoming technical problems, because dealing with e-resources incorrectly and access to poor information could lead learners to waste their time and effort; this may also be a major cause of negative attitudes towards the use of e-resources. Interestingly, students' attitudes "and perceptions also influence the level of utilization" (Kinengyere, 2007), so we need to examine the attitudes to understand the factors that affect the use of e-resources among learners.

In the literature there are a number of studies aimed to examine the attitudes of learners towards the use of e-resources in which some indicated that the respondents have positive attitudes towards e-resources. In Saudi Arabia, it is clear that the primary language is Arabic. The main source of English language in Saudi Arabia was the British colonialist. Although the British greatly encouraged the use of English, Saudi Arabians did not adopt this language fully (The British Council, 2002). One of the reasons was that education was not compulsory. 
Because of this, most students did not learn it properly. Available sources show that education from pre-school through college is considered free but not compulsory. Consequently this is one of the reason why learning English was adopted slowly by Saudis (The British Council, 2002). The educational sector has now formulated policies that dictate English competency among all students (Krane, 2009, p. 90). When the students are being admitted, they now have to sit for a placement examination and pass it to prepare them for postgraduate study, library research, and the requirements in a career (Nunan, 1998).

Available sources indicate that Saudi students' knowledge of and attitude towards the use of e-resources on BBC Learning English has improved significantly (Goldschmidt, 2005). One of the reasons why students' attitudes towards the use of e-resources is improving is that the development of new universities has forced the students to realize that learning is a collaborative issue that entails sharing of ideas (Kepel et al., 2007). For instance, the realization of the need for e-resource BBC English learning came into the minds of the Saudi Arabian students following establishment of Jeddah's King Abdulaziz University. The development of this university has forced the Saudi students to realize the importance of e-resources in the technology field (Alharbi, 2000, p. 32). Consequently, it is clear that the use of English is an inevitable requirement for Saudi Arabian students. Scholars like Alkhatib have also been involved in supporting the increased English usage and teaching in the country (Alkhatib, 1995, p. 3).

The importance of e-resources on BBC Learning English is significant; great benefits are drawn from those resources and benefit people worldwide when learning English. Studying students' attitudes towards e-resources is also an important issue in order to improve knowledge, as both variables are considered important when utilizing the e-resources on BBC Learning English.

In addition to the previous premises, there are some reasons for the potential need in Saudi Arabia for e-learning in which BBC Learning English is included. Firstly, in remote areas where the population may not have ready access to colleges and universities there is an enhanced need for e-learning, according to Alasmari and Khan (2014). Secondly, it is essential to meet the challenges of rapid scientific advances and shifting market conditions for superior opportunities without a rise in fees, according to Alasmari (2005). Thirdly, despite the strong support for the adoption of e-learning programs, which is evident in the considerable increase in Saudi Arabia's budget appropriation for education (Alasmari \& Khan, 2014), it is important to increase awareness of the benefits of e-learning technologies. In this context, Alshehri (2010) asserted that, in order to benefit from e-learning, clear vision and strategic planning with prospective e-learners in mind are essential to make e-learning programs a big success.

Based on these several essential dimensions, in light of the reality of English learning and teaching in Saudi Arabia, this study - the subject of which is notably absent in the educational context of this country - sought to investigate two variables: the knowledge of e-resources on BBC Learning English and attitudes towards it, using Saudi English students in the UK. Five hypotheses were extracted and tested in relation to these variables while testing how they are affected by demographic variables such as their gender, age and reason for learning.

\subsection{The Aim of the Study}

This study will investigate the relationship between two dependent variables, the knowledge of and attitudes towards e-resources on BBC Learning English. A questionnaire will used to collect data from more than 30 respondents. The part of the knowledge consists on 11 items that require a correct answer out of four multiple choice answers, while the part of attitude consists of 13 questions that are answered on a 5-point Likert scale.

\subsection{Operation of the Study's Constructs}

The two constructs that are to be measured within this study are knowledge of e-resources and students' attitudes towards the e-resources. These were put into practice as follows:

A. Background data:

- $\quad$ Age group: Participants ticked 20-30 or from 31-40.

- Gender: Participants chose male or female.

- A reason for learning English: Participants ticked postgraduate, undergraduate, or other.

B. The knowledge of e-resources:

This refers to the ability of students from Saudi Arabia, who are studying at three English schools in Exeter (Exeter Academy, Globe English Center, INTO University of Exeter) in 2014/2015. They were asked to answer questions testing their knowledge of e-resources on BBC Learning English. The test consisted of 11 closed, multiple choice questions. The proportion of test scores reflects the level of knowledge among participants. 
C. Students' attitudes towards the e-resources:

An attitude scale was used to measure the respondents' sentiments and feelings towards using the e-resources. It was a 5-point Likert scale consisting of 15 statements to which the respondents should respond with what they think is the most appropriate answer. Each statement was valued in a range of 1 to 5, where (1) stands for Strongly Agree; (2) stands for Agree; (3) stands for Neither Agree nor Disagree; (4) stands for Disagree; and (5) stands for Strongly Disagree.

\subsection{Definitions}

BBC Learning English is a website containing many programs that are available for listen/read/download online to help many people to learn the English language.

Saudi students are from the Arab region and are studying at three English schools in Exeter (Exeter Academy, Globe English Center, INTO University of Exeter) in 2014/2015.

\section{Hypotheses}

The proposed study is directed to explore Knowledge of and Attitudes towards e-resources on BBC Learning English: Variations among Saudi students in Exeter. In order to achieve the previous objectives, the following hypotheses were developed and investigated:

Hypothesis 1: The relationship between knowledge of and attitudes towards e-resources on BBC Learning English.

H1: There will be a significant correlation between respondents' knowledge of and attitudes towards e-resources on BBC Learning English.

H01: There will be no significant correlation between respondents' knowledge of and attitudes towards e-resources on BBC Learning English.

\begin{tabular}{lll}
\hline Independent variable & $>$ & Knowledge of e-resources on BBC Learning English. \\
& $>\quad$ Attitudes towards e-resources on BBC Learning English. \\
\hline Statistical test & A multiple linear regression test (stepwise). \\
\hline
\end{tabular}

Hypothesis 2: The effect of respondents' gender on attitudes towards e-resources on BBC Learning English.

$\mathrm{H} 2$ : There will be statistically significant differences in attitude towards e-resources on BBC Learning English between male and female respondents.

H02: There will be no statistically significant differences in attitude towards e-resources on BBC Learning English between male and female respondents.

\begin{tabular}{ll}
\hline Independent variable & Gender \\
\hline Dependent variable & Attitudes towards e-resources on BBC Learning English. \\
\hline Statistical test & Independent samples t-test. \\
\hline
\end{tabular}

Hypothesis 3: The effect of respondents' age groups on knowledge of e-resources on BBC Learning English.

H3: There will be statistically significant differences in knowledge of e-resources on BBC Learning English between respondents who are between ( 20 and 30$)$ and those who are between ( 31 and 40 ).

H03: There will be no statistically significant differences in knowledge of e-resources on BBC Learning English between respondents who are between (20 and 30) and those who are between (31 and 40).

\begin{tabular}{ll}
\hline Independent variable & Age. \\
\hline Dependent variable & Knowledge of e-resources on BBC Learning English. \\
\hline Statistical test & Independent samples t-test. \\
\hline
\end{tabular}

Hypothesis 4: The effect of the reason for learning English for respondents on attitude towards e-resources on BBC Learning English.

H4: There will be statistically significant differences in attitude towards e-resources on BBC Learning English 
between respondents who will study at postgraduate, undergraduate, or other.

H04: There will be no statistically significant differences in attitude towards e-resources on BBC Learning English between respondents who will study at postgraduate and undergraduate or other.

\begin{tabular}{ll}
\hline Independent variable & Reason for learning English \\
\hline Dependent variable & Attitude towards e-resources on BBC Learning English. \\
\hline Statistical test & One way between groups ANOVA. \\
\hline
\end{tabular}

Hypothesis 5: The prediction of knowledge of e-resources on BBC Learning English from a cluster of information on attitude towards e-resources on BBC Learning English, on age group and gender.

H5: Knowledge of will be predictable using a cluster of information on attitude towards e-resources on BBC Learning English, on age group and gender.

H05: Knowledge of will not be predictable using a cluster of information on attitude towards e-resources on BBC Learning English, on age group and gender.

\begin{tabular}{ll}
\hline Independent variable & $>$ Attitude towards e-resources on BBC Learning English. \\
& $>$ Age group. \\
& $>$ Gender. \\
\hline Dependent variable & Knowledge of e-resources on BBC Learning English. \\
\hline Statistical test & A multiple linear regression test (stepwise). \\
\hline
\end{tabular}

\section{Methodology}

This section will provide the information regarding research design, participants and sampling including data collection, measuring instrument, ethical issues and the validity and the reliability of the instrument.

\subsection{Research Design}

The methodology used in this investigation follows survey research. According to Verma and Mallick (1999), "The survey has come to be one of the most widely employed tools in educational research". A closed questionnaire was used to meet the aims of this study; it is considered an appropriate tool in the collection of data. Oppenheim $(1992$, p115) stated that "Closed questions are useful in that they can generate frequencies of response amenable to statistical treatment and analysis. They also enable comparisons to be made across groups in the sample."

\subsection{Participants and Sampling}

Population in this study refers to 28 students from Saudi Arabia who were studying English language at three English schools in Exeter (Exeter Academy, Globe English Center, INTO University of Exeter) in 2014/2015. A total of 28 participants took part in this study, 17 male and 11 female. Noticeable in this study was that the number of male students was larger than the number of female students. In terms of age, the number of participants aged (20-30 years old) was 12 students (42.9\%), and aged (31-40 years old) was 16 students (57.1\%). In addition, it was stated by $11(39.3 \%)$ of the participants that their reason behind learning English was to pursue postgraduate studies; 10 (35.7\%) participants learnt English for undergraduate study, and 7 (25\%) stated other reasons.

The sample was chosen based on convenience sampling of 28 participants. The reason behind that selection included that the time scheduled for the study was short; and the study was not intended for generalisation of the results. I took the opportunity at a meeting of the Saudi Society on 7th April 2012 and I distributed the questionnaire for all the attendants at this meeting after I had explained the aim of the study and provided some information concerning important ethical issues. Then each participant gave me his/her questionnaire after they had completed it. 


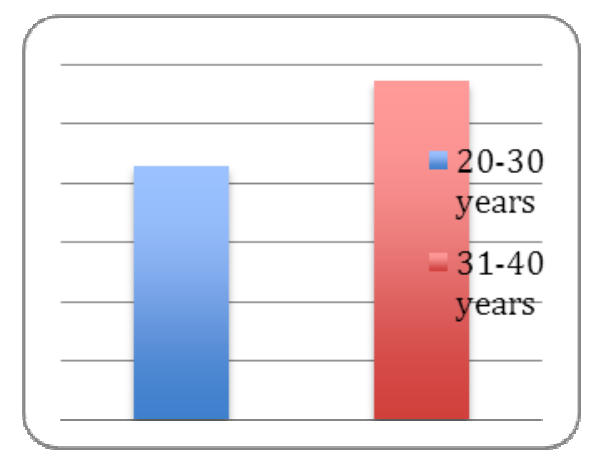

Figure 1. The percentage of participants' based on two age groups

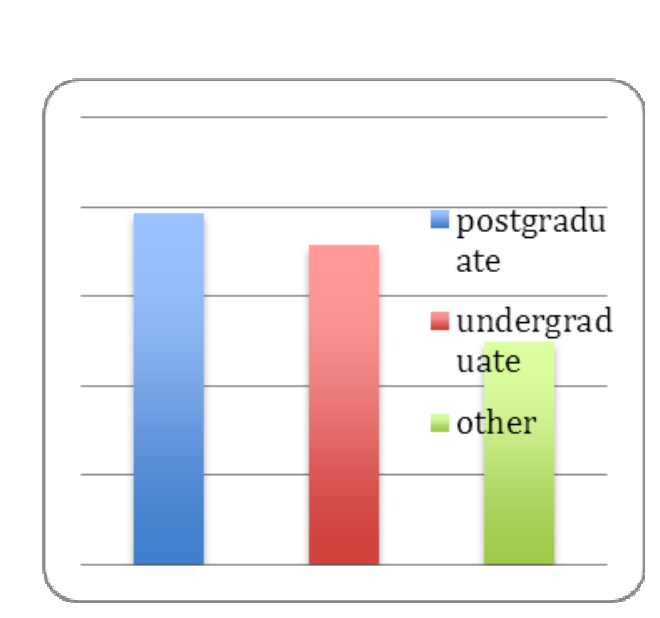

Figure 3. The reason for learning english using e-resources on BBC learning English

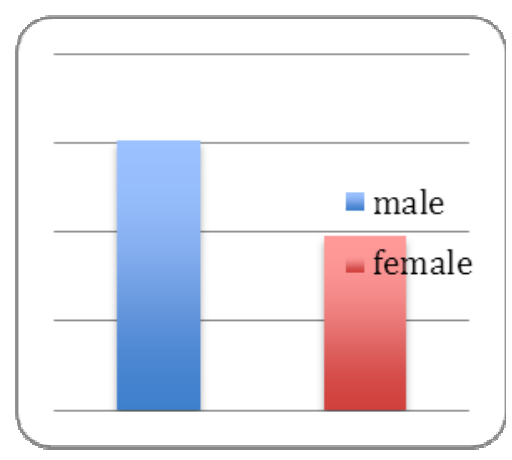

Figure 2. Participants' gender

\subsection{Ethics}

To ensure an ethical study, according to British Educational Research Association (2004), the participants were informed about the aim of this study, confidentiality, anonymity, the right to withdraw, and informing participants of the research results.

\subsection{Measuring Instrument}

The designed questionnaire was divided into three main sections (Appendix 1): demographic information (gender, age, reason for learning English), knowledge of using e-resources on BBC Learning English test (measured through 11 items. Each question has 4 choices which were rated as either correct or wrong) and attitudes towards using of e-resources on BBC Learning English (15 items, measured on a 5-point Likert scale). The designed questionnaire was in English.

\subsection{The Validity of the Instrument}

Oppenheim (1992:144) stated that validity "tells us whether the question, item or score measures what it is supposed to measure". The items of the instrument were tested by content validity. They were revised to check the validity by experts from the Graduate School of Education at the University of Exeter. Also, they were revised by three MSc students. Both efforts helped to obtain feedback to reconstruct the questionnaire in light of formative assignment feedback as well (e.g. emphasizing some items and excluding others such as, "Have you ever used BBC Learning English").

\subsection{The Reliability of the Instrument}

The reliability of a questionnaire it is free of random errors. According to Oppenheim (1992:144) reliability means "the purity and consistency of a measure, to repeatability, to the probability of obtaining the same results 
again if the measure were to be duplicated". Internal consistency as a type of reliability was used in this study, measured by Cronbach's alpha. This measure produces a coefficient that shows how consistent scores are with each other and reflects a value between 0 and $100 \%$ consistency $(0-1)$. As you can see, the results of the Cronbach's alpha for the knowledge scale of 11 items showed that reliability is 0.797 and the attitude on the 15 items scale showed that reliability is 0.925 . According to Gaur (2009:134) "a value of Cronbach alpha above 0.70 can be used as a reasonable test of scale reliability". Since these results showed high reliability, both measures can be used to explain participants' knowledge of and attitude towards using the e-resources on BBC Learning English.

Table 1. The reliability of knowledge of e-resources on BBC Learning English

\begin{tabular}{ll}
\hline Reliability Statistics & \\
Cronbach's Alpha & N of Items \\
\hline .797 & 11 \\
\hline
\end{tabular}

Table 2. The reliability of attitude towards e-resources on BBC Learning English

\begin{tabular}{ll}
\hline Reliability Statistics \\
Cronbach's Alpha & N of Items \\
\hline .925 & 15 \\
\hline
\end{tabular}

\section{Presentation of Results}

\subsection{Normality of Data}

The normality of data was tested through Kolmogorov-Smirnov and Shapiro-Wilk tests; both of these tests explain whether the data satisfy normal distribution or not. The tests assume that the null hypothesis is that the data comes from normal distribution, therefore a significant result $(\mathrm{p}<0.05)$ will lead to the rejection of this assumption, otherwise the data can be assumed normal. The main variables of concern in this data are the knowledge of e-resources on BBC Learning English and the attitude towards it. The tests were conducted and the results revealed insignificant outcome for both variables (see Tables $1 \& 2$ ). This explains that the null hypothesis is correct and that the data comes from normal distribution. The normality of the data along with the interval scale used in both variables leads to the conclusion that the data is parametric; hence parametric tests should be used to test the corresponding hypotheses (see Appendix 2).

Table 3. The normality statistics through Kolmogorov-Smirnov and Shapiro-Wilk for the knowledge scale

\begin{tabular}{lllllll}
\hline Tests of Normality & \multicolumn{7}{l}{ Shapiro-Wilk } \\
\hline & \multicolumn{3}{l}{ Kolmogorov-Smirnov ${ }^{\mathrm{a}}$} & \multicolumn{3}{l}{ Sig. } \\
\cline { 2 - 7 } & Statistic & Df & Sig. & Statistic & Df & .058 \\
\hline Total. Knowledge & .172 & 28 & .033 & .929 & 28 & \\
\hline \multicolumn{2}{l}{ a. Lilliefors Significance Correction } & & & & \\
\hline
\end{tabular}




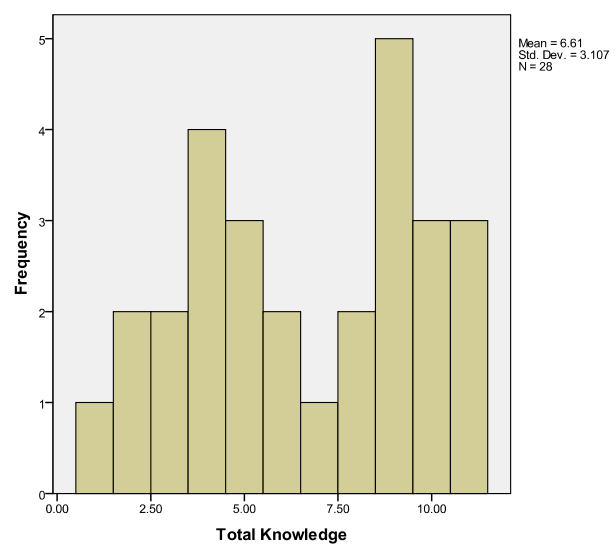

Figure 4. The distribution of results in knowledge

Table 4. The normality statistics through Kolmogorov-Smirnov and Shapiro-Wilk for the attitude scale

\begin{tabular}{|c|c|c|c|c|c|c|}
\hline \multicolumn{7}{|c|}{ Tests of Normality } \\
\hline & \multicolumn{3}{|c|}{ Kolmogorov-Smirnov $^{\mathrm{a}}$} & \multicolumn{3}{|c|}{ Shapiro-Wilk } \\
\hline & Statistic & Df & Sig. & Statistic & Df & Sig. \\
\hline $\begin{array}{l}\text { Mean. } \\
\text { Attitude }\end{array}$ & .068 & 28 & $.200^{*}$ & .985 & 28 & .946 \\
\hline
\end{tabular}

a. Lilliefors Significance Correction

*This is a lower bound of the true significance.

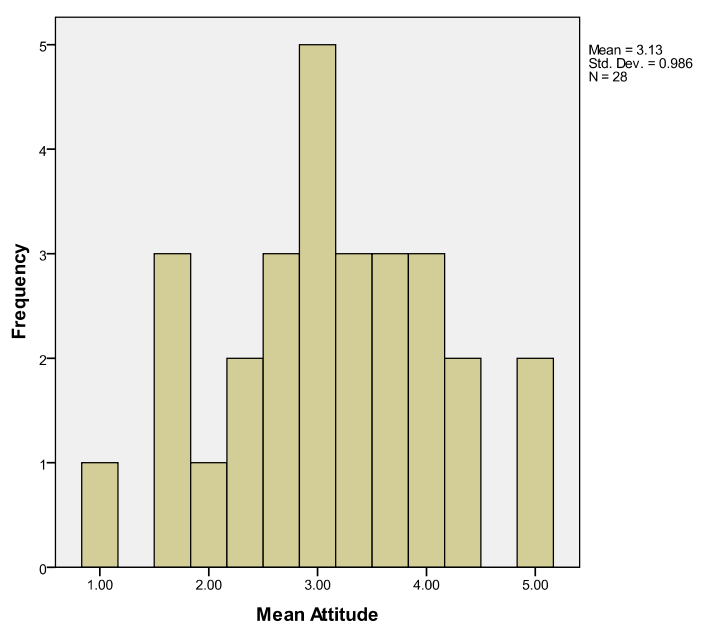

Figure 5. The distribution of results in attitude

\subsection{Inferential Statistics}

1) The relationship between knowledge of and attitudes towards e-resources on BBC Learning English.

A Pearson's $r$ correlations coefficient was calculated using SPSS to measure the extent of the relationship between students' knowledge of e-resources and the attitude towards it among Saudi students at Exeter University. The results of the correlation coefficient showed a medium and a significant positive relationship between both variables, $\mathrm{r}(28)=0.436, \mathrm{p}=0.020$. The significance level here was smaller than $5 \%$ which is the maximum acceptable level of probability that the results happened by accident. This result means that regarding the increase in knowledge, there is an increase in the positive attitude towards e-resources (see Table 3). 
Table 5. Represents the correlation coefficient and the significance value between knowledge and attitude

\begin{tabular}{llll}
\hline Correlations & & & \\
\hline & & Total Knowledge & Mean Attitude \\
\hline Total & Pearson Correlation & 1 & $.436^{*}$ \\
Knowledge & Sig. (2-tailed) & & .020 \\
& $\mathrm{~N}$ & 28 & 28 \\
Mean Attitude & Pearson Correlation & $.436^{*}$ & 1 \\
& Sig. (2-tailed) & .020 & \\
& $\mathrm{~N}$ & 28 & 28 \\
\hline
\end{tabular}

*Correlation is significant at the 0.05 level (2-tailed).

2) The effect of respondents' gender on attitudes towards e-resources on BBC Learning English.

To analyze this hypothesis it is essential to use an Independent Samples t-test which measures the difference between two independent groups (genders) based on a dependent variable (attitude towards e-resources). By doing so it was found that the gender did not have a significant effect on the attitude, the $t(26)=0.397, p=0.695$. The probability was not significant $(\mathrm{p}>0.05)$ and hence it was concluded that both genders male (Mean $=3.07)$ and Female (Mean=3.22) had a similar positive attitude towards e-resources.

Table 6. The difference between genders based on attitude

\begin{tabular}{llllllll}
\hline Independent Samples Test & \multicolumn{1}{l}{} \\
\hline & & $\begin{array}{l}\text { Levene's } \\
\text { Variances }\end{array}$ & Test for Equality & of & $\begin{array}{l}\text { t-test for Equality of } \\
\text { Means }\end{array}$ \\
\cline { 3 - 7 } & $\mathrm{F}$ & Sig. & $\mathrm{t}$ & $\mathrm{Df}$ \\
\hline $\begin{array}{l}\text { Mean. } \\
\text { Attitude }\end{array}$ & Equal variances assumed & .120 & .732 & -.397 & 26 \\
\cline { 2 - 7 } & Equal variances not assumed & & & & -.394 & 21.029 \\
\hline
\end{tabular}

3) The effect of respondents' age groups on knowledge of e-resources on BBC Learning English.

This hypothesis seeks to measure the effect of age from two independent groups (20-30 years old and 31-40 years) on the knowledge of e-resources on BBC Learning English. Using an Independent Samples t-test the results explained that age had an effect on the knowledge variable. The younger group of participants showed a significantly lower knowledge average (Mean=5.00) compared to the older group of participants (Mean=7.81), the results were significant at $\mathrm{t}(26)=2.61, \mathrm{p}=0.015(\mathrm{p}<0.05)$. Hence the knowledge of participants appears to be shaped by their age.

Table 7. The difference between age groups based on knowledge

\begin{tabular}{|c|c|c|c|c|}
\hline \multicolumn{5}{|c|}{ Independent Samples Test } \\
\hline & & $\begin{array}{l}\text { Levene's Test for Equality of } \\
\text { Variances }\end{array}$ & $\begin{array}{l}\text { t-test } \\
\text { Means }\end{array}$ & Iality of \\
\hline & & Sig. & $\mathrm{t}$ & Df \\
\hline \multirow{2}{*}{$\begin{array}{l}\text { Total } \\
\text { Knowledge }\end{array}$} & Equal variances assumed & .244 & -2.614 & 26 \\
\hline & Equal variances not assun & & -2.559 & 21.806 \\
\hline
\end{tabular}

4) The effect of the reason for learning English for respondents on attitude towards e-resources on BBC Learning English.

This hypothesis enquires about the effect of reasons for learning English (postgraduate, undergraduate, and other 
reasons) on the attitude towards resources on BBC Learning English. Three independent groups (levels of the independent variable) are identified here. To test their effect on the attitude a One Way Analysis Of Variance (ANOVA) was used. It was gathered that the reasons behind learning English did not significantly affect the attitude towards e-resources, $\mathrm{F}(2,25)=2.84, \mathrm{p}=0.077$. However by looking at the LSD post-Hoc test (compares the groups together) it was found that there was no significant difference between the undergraduate and postgraduate groups $(\mathrm{p}>0.05)$, but there was a significant difference between both of these groups and the Other group $(\mathrm{p}<0.05)$. The postgraduate reason had a mean of 3.37 , followed by the undergraduate reason with 3.36 and finally the other reason which had a low mean attitude of 2.40 (see Appendix 6).

Table 8. The ANOVA value between participants based on the attitude score

\begin{tabular}{llllll}
\hline ANOVA & & & & \\
\hline Mean. Attitude & & & & \\
\hline & Sum of Squares & Df & Mean Square & F & Sig. \\
\hline Between Groups & 4.858 & 2 & 2.429 & 2.842 & .077 \\
\hline Within Groups & 21.368 & 25 & .855 & & \\
\hline Total & 26.227 & 27 & & & \\
\hline
\end{tabular}

5) The prediction of knowledge of e-resources on BBC Learning English from a cluster of information on attitude towards e-resources on BBC Learning English, on age group and gender.

This hypothesis explains that the knowledge of e-resources (dependent variable) can be predicted through the attitude towards e-resources, age and gender (independent variables or predictors). To test this hypothesis a multiple linear regression was used; this regression produced a significant model which had an ANOVA score of $\mathrm{F}(1,26)=6.83, \mathrm{p}=0.015$, which shows that the model is good enough to explain the changes occurring in the dependent variable. The r-square explains that the model as a whole is responsible for $20.8 \%$ of the changes occurring in the knowledge variable. When looking at each predictor individually it was found that only the Age variable can be considered a significant predictor of the knowledge; it had a standardized Beta of 0.456 , which is the total variances explained by this variable in the dependent variable; i.e. for an increase in the age variable there is a change of 0.456 in the knowledge variable (see Appendix 7).

Table 9. Includes the regression model summary and the variances explained by it

\begin{tabular}{llllll}
\hline Model Summary & \multicolumn{1}{l}{} \\
\hline Model & $\mathrm{R}$ & $\mathrm{R}$ & $\begin{array}{l}\text { Adjusted } \\
\text { Square }\end{array}$ & $\mathrm{R}$ & Std. Error of the Estimate \\
\hline dimension0 & 1 & $.456^{\mathrm{a}}$ & .208 & .178 & 2.81778 \\
\hline
\end{tabular}

a. Predictors: (Constant), Age

Table 10. The ANOVA result showing the significance of the model

\begin{tabular}{lllllll}
\hline ANOVA $^{\mathbf{b}}$ & & & & \\
\hline \multicolumn{2}{l}{ Model } & Sum of Squares & Df & Mean Square & F & Sig. \\
\hline \multirow{2}{*}{1} & Regression & 54.241 & 1 & 54.241 & 6.831 & $.015^{\text {a }}$ \\
\cline { 2 - 6 } & Residual & 206.438 & 26 & 7.940 & & \\
\cline { 2 - 6 } & Total & 260.679 & 27 & & & \\
\hline
\end{tabular}
a. Predictors: (Constant), Age
b. Dependent Variable: Total Knowledge 
Table 11. Includes the significant predictor of the knowledge

\begin{tabular}{|c|c|c|c|c|c|c|}
\hline \multicolumn{7}{|c|}{ Coefficients $^{\mathrm{a}}$} \\
\hline \multirow{2}{*}{\multicolumn{2}{|c|}{ Model }} & \multicolumn{2}{|c|}{ Unstandardized Coefficients } & Standardized & \multirow[t]{2}{*}{$\mathrm{t}$} & \multirow[t]{2}{*}{ Sig. } \\
\hline & & B & Std. Error & Beta & & \\
\hline \multirow[t]{2}{*}{1} & (Constant) & 2.188 & 1.773 & & 1.234 & .228 \\
\hline & Age & 2.812 & 1.076 & .456 & 2.614 & .015 \\
\hline
\end{tabular}

a. Dependent Variable: Total Knowledge.

\section{Discussion}

This study investigated two variables, the knowledge of e-resources on BBC Learning English and attitude towards it, using Saudi English students within the UK. Five hypotheses were extracted and tested in relation to these variables while testing how they are affected by demographic variables such as the Gender, Age and Reason for learning. This section will summarize the findings and discuss them in relation to previous research.

1) The relationship between knowledge and attitude:

The results concerning the relationship between the knowledge of e-resources on BBC Learning and the attitude towards it indicated significant positive association, hence the hypothesis can be accepted and the null hypothesis will be rejected. It appeared that the higher the knowledge the better or more positive attitude the students will have towards e-resources on BBC Learning. These results confirm previous research by Goldschmidt (2005) which explained that Saudi Arabian students' knowledge of and attitude towards the use of e-resources on BBC Learning English has improved significantly (Goldschmidt, 2005). One of the main reasons that contribute to this improvement is the development of new universities in Saudi Arabia which greatly stress on the importance of learning the English language as a core module in order to succeed. Furthermore the realization of the need for e-resource BBC Learning English has become an important factor for Saudi Arabian students after the establishment of Jeddah's King Abdulaziz University of Science and Technology. The development of this university has led the Saudi students to realize the importance of e-resources in the field of technology (Alharbi, 2000). This main reason could be behind the positive relation between the knowledge of and the attitude towards e-resources on BBC Learning English. Other reasons might include the fact that technology has become a predominant part of our lives and that electronic learning is an advantage to many who prefer it compared to traditional learning methods; this could lead to more access to information and knowledge and lead to more positive attitudes towards using e-resources.

2) The effect of respondents' gender on attitudes:

It was hypothesized that the gender will have an effect on the attitude towards e-resources. The results indicated that this hypothesis is rejected and as a result the null hypothesis can be accepted, meaning that the gender does not have an effect on the attitude score. Nowadays the use of computers is common among Saudi students, most of whom are aware of the internet usage and electronic learning, equally male and female Saudi students have access to both, and the sample in this study were all Saudi students who were keen on learning English. One of the main ways of doing so is through the e-resource of BBC Learning English, therefore the usage and the usefulness of such a facility might have led to better attitudes among all students regardless of their gender. One of the main limitations of this study is the small number of participants, especially when comparing three independent groups, and as a result the generalisability of this result is limited.

3) The effect of respondents' age groups on knowledge:

The third hypothesis sought to measure the effect of age (2 groups) on the knowledge of e-resources on BBC Learning English. It was found that the older group of the participants (31-40) showed higher knowledge compared to the younger group (20-30), therefore the hypothesis was confirmed and the null hypothesis was rejected. One can assume that the older the participant the more access to internet and electronic resources he/she might have had, and experience of using e-resources in general and of BBC Learning English in particular; this as a result might lead to an increased knowledge compared to the younger generation. Furthermore the older participants might see the importance of e-resources and its usefulness more than the younger group; this might lead to more usage and more knowledge. Although previous research did not touch on how the knowledge of e-resources could be affected by the age it is essential to understand that the current study used a small sample of 
participants and there were only two age groups, hence more understanding of the age affect could be gained had the age variable been measured on an interval scale rather than a categorical one, that way it would be easier to correlate age and its development with the knowledge.

4) The effect of respondents' reason for learning English on their attitude:

The fourth hypothesis explained that there should be an effect of participants' reason for studying on their attitude. The results indicated that overall no significant effect was found for the reason on the attitude. Despite generating a significant difference between those who chose the postgraduate reason compared to the other reasons, participants answering other reasons showed significantly lower attitude. The hypothesis is rejected but this difference can be of great interest.

Having a reason behind learning English could be crucial in improving the attitude: people who are keen on learning might use all possible methods to increase their knowledge, but on the other hand those who are forced or required to learn might develop a bad attitude towards learning in general. In this study although those who aimed for postgraduate study as a reason for learning showed similar attitude to the ones who learn for an undergraduate reason, those who chose Other reasons showed poor to negative attitude, which might explain that their reason behind learning is not strong enough and as a result the attitude is poor, but the overall difference was not significant hence no generalisability could be made. The issue of the small sample can be raised again as a limitation, also those who answered other reasons should perhaps include their exact reason for learning. In that way the reason for learning English through e-resources could be explained better in relation to the attitude.

5) The prediction of knowledge:

The final hypothesis assumed that the knowledge of e-resources can be predicted through the attitude towards e-resources, age and gender (independent variables or predictors). It was found that only the Age variable can be considered a significant predictor of the knowledge, i.e. researchers can use the age variable to significantly predict variances and changes happening in the knowledge of e-resources on BBC Learning English. The significance of age as a predictor supports findings in the third hypothesis and further indicates the importance of age when investigating knowledge of e-resources. Even though the attitude was correlated significantly with the knowledge of e-resources (see Hypothesis 1) the results were not significant enough to indicate that the attitude can predict knowledge; this could be as a result of the small number of participants and due to the medium strength of the relationship between both variables.

\section{Conclusion}

The importance of e-resources on BBC Learning English is significant: great benefits are drawn from those resources and benefit people worldwide when learning English. The importance of studying students' attitude towards e-resources is still an important issue in order improve knowledge as both variables are considered significant when utilizing the e-resources on BBC Learning English.

This study investigated how the knowledge of e-resources is linked with the attitude towards them. Using a sample of Saudis who are studying English in the UK it was generated that their knowledge of and the attitude towards e-resources on BBC Learning English are positively correlated; a positive increase in one variable lead to an improved outcome in the other, which further stresses the importance of having a positive attitude as a way of gaining more knowledge on e-resources. Gender was not found to affect the attitude towards e-resources, however age seemed to have an effect on the knowledge, and older participants had more knowledge. Even though participants had varied reasons for studying English and using e-resources on BBC Learning their knowledge outcome was not affected by that. This study did not go without criticism as it used a small convenience sample of Saudi students and administered the questionnaire over a short period of time, hence future research should benefit from increasing the sample size to an acceptable size to ensure that the outcome can be generalisable to the whole population.

\section{References}

Alasmari, A. M., \& Rabb Khan, M. S. (2014). E-learning in Saudi Arabia: Past, present and future. Near and Middle Eastern Journal of Research in Education, 2. https://doi.org/10.5339/nmejre.2014.2

Alasmari A. (2005). The use of internet among EFL teachers at the colleges of technology in Saudi Arabia. Dissertation, Ohio University.

Alharbi, L. M. (2000). Local and ENS rating of EFL composition in Arabic 'culturolinguistic' context. London: Bawlink.

Alkhatib, J. (1995). Processes and their products: A comparison of task sequences and outcomes in EAP writing 
classes. New York: SAGE.

Al-Shehri, A. M. (2010). E-learning in Saudi Arabia: 'To E or not to E, that is the question'. Journal of family and community medicine, 17(3), 147. https://doi.org/10.4103/1319-1683.74333

The British Council. (2002). British council: international education marketing. http://80.227.105.236/arpq/British\%20Council\%20Education\%20Market\%20Report\%20EDUKEX\%20200 2.

Charise, A. (2007). More English, Less Islam? An Overview of English Language Functions in the Arabian/Persian Gulf, http://homes.chass.utoronto.ca/ cpercy/courses/eng6365-charise.

Goldschmidt, A. (2005). A Concise History of the Middle East. Boulder: West View Press.

Kepel, G., \& Ghazaleh, P. (2007). The war for Muslim minds: Islam and the West. Cambridge, MA: Belknap Press of Harvard University Press.

Kinengyere, A. (2007). The effect of information literacy on the utilization of electronic information resources in selected academic and research institutions in Uganda. The Electronic Library, 25(3), 328-341. https://doi.org/10.1108/02640470710754832

Krane, J. (2009). Al-Jazeera Launches Service in English. http://www.abcnews.go.edu/Entertainment/wireStory?id=2654637.

MacWhinnie, L. A. (2003). The Information Commons: the academic library of the future. Portal: Libraries and the Academy, 3(2), 241-257. https://doi.org/10.1353/pla.2003.0040

Madhusudhan, M. (2010). Use of electronic resources by research scholars of Kurukshetra University. The Electronic Library, 28(4), 492-506. https://doi.org/10.1108/02640471011033684

Allison, D., Cooley, L., Lewkowicz, J., \& Nunan, D. (1998). Dissertation writing in action: The development of a dissertation writing support program for ESL graduate research students. English for specific purposes, 17(2), 199-217. https://doi.org/10.1016/S0889-4906(97)00011-2

Okello-Obura, C. (2010). Assessment of the problems LIS postgraduate students face in accessing e-resources in Makerere University, Uganda. Collection Building, 29(3), 98-105. https://doi.org/10.1108/01604951011060385

Oppenheim, A. N. (1992) Questionnaire Design, Interviewing and Attitude Measurement: New Edition. London: Pinter.

Thachil, G. (2008). Academic libraries redefined: old mission with a new face. Scroll, 1(1). In C. Okello-Obura, \& J. R. Ikoja-Odongo (2010). Electronic information seeking among LIS postgraduate students at Makerere University, Uganda.

Verma, G., \& Mallick, K. (1999). Researching Education: Perspective and Techniques. London- Falmer Press.

\section{Appendices}

\section{Appendix A:}

Questionnaire:

An investigation into the Saudi students' knowledge of and attitudes towards e-resources on BBC Learning English

Dear participant,

BBC Learning English provides topical multimedia content for people all over the world who want to speak English. I am conducting research to investigate the Saudi students' knowledge of and attitudes towards e-resources on BBC Learning English.

I would be grateful if you answer each item in this questionnaire. Since your answers will be just used for academic purposes, all answers and your identity will be kept confidential. Finally, with pleasure, you have the right to withdraw in any time you would like.

The researcher,

Khalid 


\section{Part 1: Demographic Data:}

Please choose the one that applies to you:
1- Age Group:
A) from 20 to 30
B) from 31 to 40
2- Gender:
A) male
B) female

3- What is the reason for your learning English?
A) Postgraduate
B) Undergraduate
C) Other

\section{Part 2: Knowledge of using the e-resource:}

Please choose the appropriate answer: (only one answer)

1- $\quad$ At BBC Learning English there are a topical multimedia content for people all over the world who want to speak English for:,
A) fun
B) work
C) study
D) all of them

2- General and Business English has many program such as,
A) 6 Minute English
B) The Flatmates program
C) Talking sport
D) For teacher
3- $\quad$ All programs and websites center at BBC Learning English around:
A) listening English
B) speaking English
C) reading English
D) learning English

4- Learning English blog on BBC Learning English related to:
A) Teachers
B) Staff
C) Students
D) all of them

5- "English at Work" is a new series of programs on BBC Learning English to help you learn some useful business language which you could use in:
A) an interview
B) a school
C) a workplace
D) all of them

6- The "Quizzes program" on BBC Learning English has many questions on different topics, they are:
A) 4 questions
B) 5 questions
C) 6 questions
D) 7 question

7- There are many characters in "The Flatmates program" on BBC Learning English, they are:
A) two characters
B) three characters
C) four characters
D) five characters

8- $\quad$ On BBC Learning English, "Follow sporting stories and learn English along the way" is the idea of:
A) The teacher program
B) Welcome to London program
C) Talking Sport program
D) 6 Minute English program

9- $\quad$ On BBC Learning English, "Every week we ask you a different question. Hear what people in London say" is the idea of
A) Welcome to London program
B) Express English program
C) The teacher program
D) English at Work program

10- On BBC Learning English, "Tell us what you think about this photo. Each month throughout 2012 we'll be focusing on a different colure" is the idea of
A) Calendar 2012 program
B) Welcome to London program
C) Express English
D) 6 Minute English

11- Pronunciation tips from BBC Learning English has many programs such as
A) Features of English
B) Welcome to London program
C) Express English
D) 6 Minute English 


\section{Part 3: attitude towards using e-resources on BBC Learning English}

Please put a tick $(\sqrt{ })$ into the following statements in the box that expresses your feelings and sentiments about attitude towards using e-resources on BBC Learning English:

$1=$ Strongly Disagree, $2=$ Disagree, $3=$ Neutral, $4=$ Agree, $5=$ Strongly Agree

\begin{tabular}{|c|c|c|c|c|c|c|}
\hline & Items Statements & 1 & 2 & 3 & 4 & 5 \\
\hline 1 & I like learning with e-resources on BBC Learning English. & & & & & \\
\hline 2 & I like to access e-resources on BBC Learning English from anywhere. & & & & & \\
\hline 3 & I feel that using the e-resources to help me to get more progress in learning English. & & & & & \\
\hline 4 & I prefer using the e-resources because they are more available. & & & & & \\
\hline 5 & I dislike using e-resources on BBC Learning English. & & & & & \\
\hline 6 & $\begin{array}{l}\text { I prefer using an English book in my school instead of using e-resources on BBC } \\
\text { Learning English. }\end{array}$ & & & & & \\
\hline 7 & $\begin{array}{l}\text { I feel that using e-resources on BBC Learning English help me to learn } \\
\text { independently. }\end{array}$ & & & & & \\
\hline 8 & I feel bored when I use e-resources on BBC Learning English. & & & & & \\
\hline 9 & I do not trust the information in e-resources on BBC Learning English. & & & & & \\
\hline 10 & I feel that using e-resources on BBC Learning English made me confused. & & & & & \\
\hline 11 & I feel that using e-resources on BBC Learning English are helpful. & & & & & \\
\hline 12 & $\begin{array}{l}\text { I feel that using e-resources on BBC Learning English enhance the learning process } \\
\text { efficiently. }\end{array}$ & & & & & \\
\hline 13 & I find e-resources on BBC Learning English hard to deal with. & & & & & \\
\hline 14 & $\begin{array}{l}\text { It is difficult to find appropriate materials for my level in e-resources on BBC } \\
\text { Learning English. }\end{array}$ & & & & & \\
\hline 15 & $\begin{array}{l}\text { I feel that e-resources on BBC Learning English enrich my knowledge of the } \\
\text { English language. }\end{array}$ & & & & & \\
\hline
\end{tabular}

Thank you for your time,

\section{Appendix B: Other information related to statistics:}

\section{Normality of Scores:}

\section{Tests of Normality}

\begin{tabular}{lllllll}
\hline & \multicolumn{5}{c}{ Kolmogorov-Smirnov $^{\mathrm{a}}$} & \multicolumn{5}{c}{ Shapiro-Wilk } \\
\cline { 2 - 7 } & Statistic & $\mathrm{df}$ & Sig. & Statistic & df & Sig. \\
\hline Total.Knowledge & .172 & 28 & .033 & .929 & 28 & .058
\end{tabular}

a. Lilliefors Significance Correction 


\section{Total Knowledge}

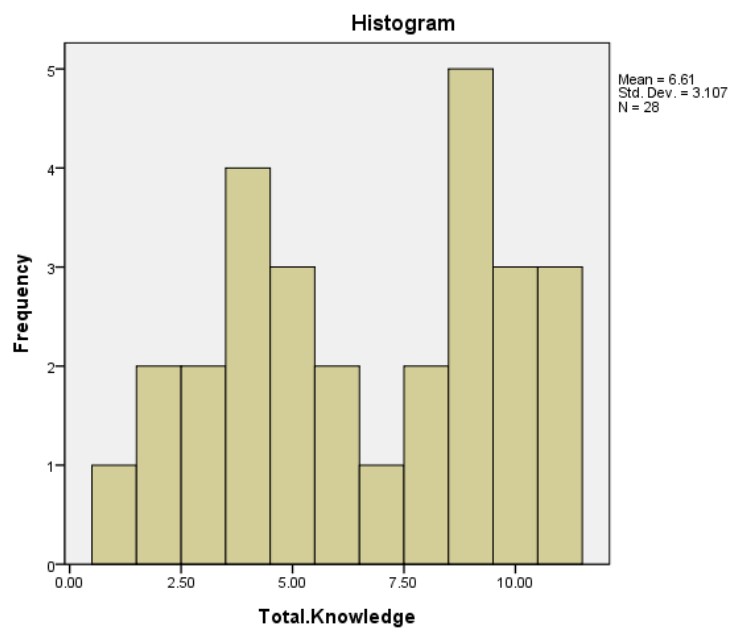

Knowledge Stem-and-Leaf Plot

Frequency Stem \& Leaf

$\begin{array}{lll}1.00 & 0 . & 1 \\ 4.00 & 0 . & 2233 \\ 7.00 & 0 . & 4444555 \\ 3.00 & 0 . & 667 \\ 7.00 & 0 . & 8899999 \\ 6.00 & 1 . & 000111 \\ \text { Stem width: } & & 10.00 \\ \text { Each leaf: } & & 1 \text { case(s) }\end{array}$

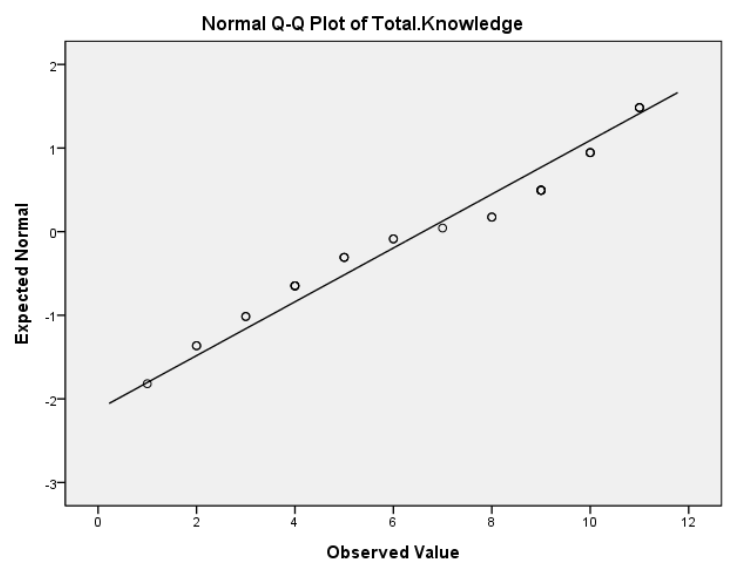



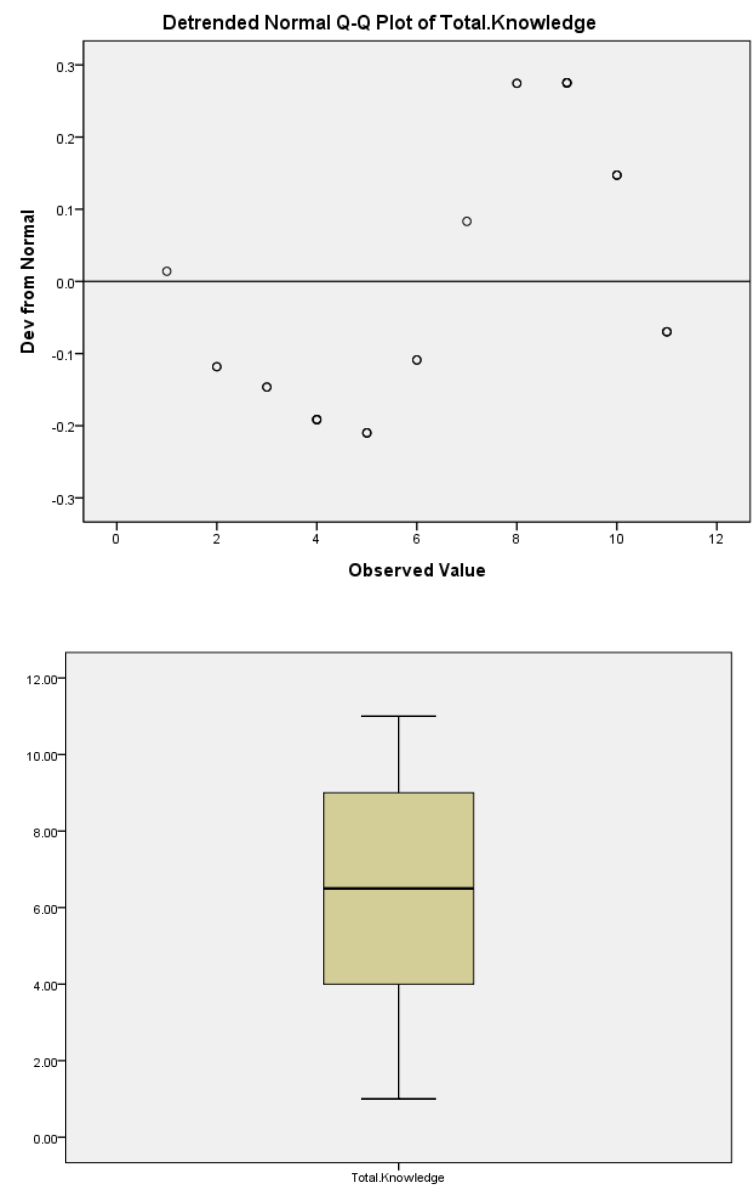

\section{Mean Attitude:}

\section{Tests of Normality}

Kolmogorov-Smirnov ${ }^{\mathrm{a}}$

Statistic

df

28

Sig.

Mean. Attitude $\quad 068$

$.200^{*}$

Shapiro-Wilk

Statistic df

28
Sig.

.946

a. Lilliefors Significance Correction

*. This is a lower bound of the true significance. 


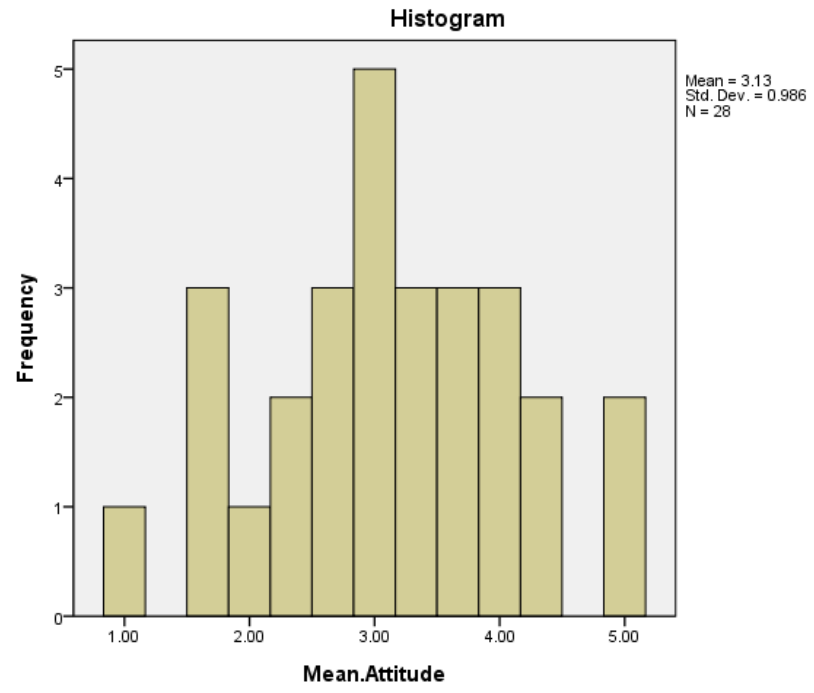

Mean. Attitude Stem-and-Leaf Plot

Frequency Stem-and-Leaf
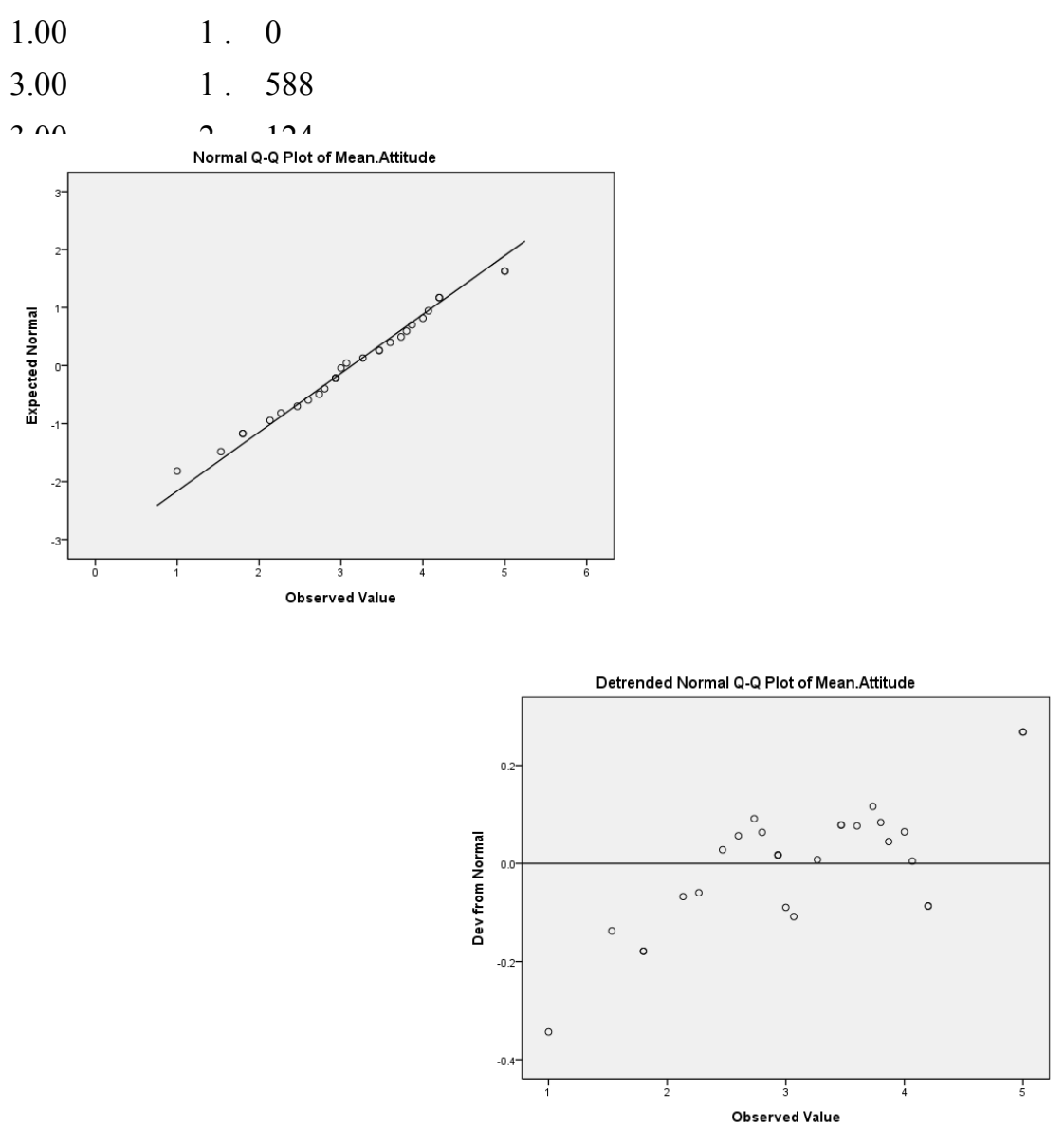


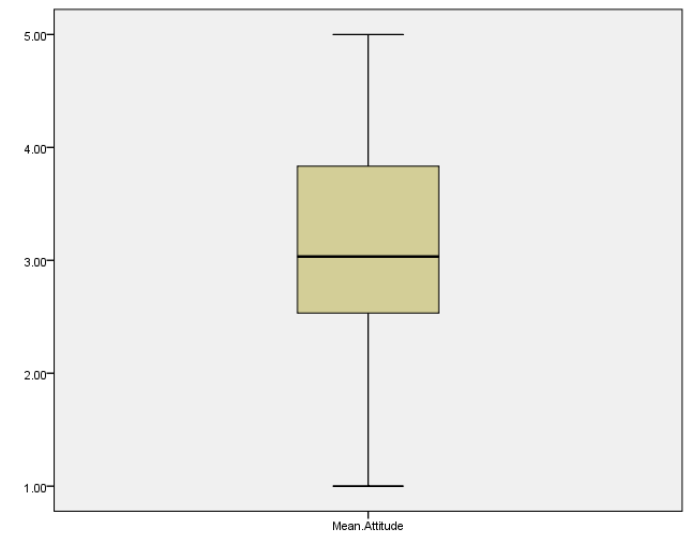

2. Correlation Between Knowledge and Attitude

\section{Correlations}

\begin{tabular}{llll}
\hline & & $\begin{array}{l}\text { Total. } \\
\text { Knowledge }\end{array}$ & Mean. Attitude \\
\hline Total.Knowledge & Pearson Correlation & 1 & $.436^{*}$ \\
\cline { 2 - 4 } & Sig. (2-tailed) & .020 \\
\cline { 2 - 4 } & $\mathrm{N}$ & 28 & 28 \\
\hline Mean. Attitude & Pearson Correlation & $.436^{*}$ & 1 \\
\cline { 2 - 4 } & Sig. (2-tailed) & .020 & 28 \\
\cline { 2 - 4 } & $\mathrm{N}$ & 28 & \\
\end{tabular}

*. Correlation is significant at the 0.05 level (2-tailed).

\section{Effect of Gender on Attitude:}

\begin{tabular}{llllll}
\hline Group Statistics & & & & & \\
\hline & gender & $\mathrm{N}$ & Mean & Std. Deviation & Std. Error Mean \\
\hline Mean. Attitude & male & 17 & 3.0706 & .98980 & .24006 \\
\cline { 2 - 6 } & female & 11 & 3.2242 & 1.01949 & .30739 \\
\hline
\end{tabular}

\section{Independent Samples Test}

\begin{tabular}{lllllll}
\hline & & $\begin{array}{l}\text { Levene's } \\
\text { Variances }\end{array}$ & & & Test for Equality & of $\begin{array}{l}\text { t-test for Equality of } \\
\text { Means }\end{array}$ \\
\cline { 2 - 7 } & & $\mathrm{F}$ & $\mathrm{Sig}$ & $\mathrm{t}$ & $\mathrm{df}$ \\
\hline Mean. Attitude & Equal variances assumed & .120 & .732 & -.397 & 26 \\
\cline { 2 - 7 } & $\begin{array}{l}\text { Equal variances not } \\
\text { assumed }\end{array}$ & & & -.394 & 21.029 \\
\hline
\end{tabular}

\section{Independent Samples Test}

t-test for Equality of Means

\begin{tabular}{lll}
\hline Sig. (2-tailed) & Mean & Std. Error Difference
\end{tabular}

Difference

\begin{tabular}{lllll}
\hline Mean. Attitude & Equal variances assumed & .695 & -.15365 & .38746 \\
\cline { 2 - 5 } & Equal variances not assumed & .698 & -.15365 & .39002 \\
\hline
\end{tabular}




\section{Independent Samples Test}

\begin{tabular}{llll}
\hline & & \multicolumn{2}{l}{ t-test for Equality of Means } \\
\cline { 3 - 4 } & & \multicolumn{2}{l}{$95 \%$ Confidence Interval of the Difference } \\
\cline { 2 - 3 } & & Lower & Upper \\
\hline \multirow{2}{*}{ Mean. Attitude } & Equal variances assumed & -.95010 & .64279 \\
\cline { 2 - 4 } & Equal variances not assumed & -.96468 & .65737 \\
\hline
\end{tabular}

\section{Effect of Age on Knowledge:}

\begin{tabular}{llllll}
\hline Group Statistics & \multicolumn{1}{l}{} & & \\
\hline & age & $\mathrm{N}$ & Mean & Std. Deviation & Std. Error Mean \\
\hline Total. Knowledge & $20-30$ years & 12 & 5.0000 & 3.04512 & .87905 \\
\cline { 2 - 6 } & $31-40$ years & 16 & 7.8125 & 2.63865 & .65966 \\
\hline
\end{tabular}

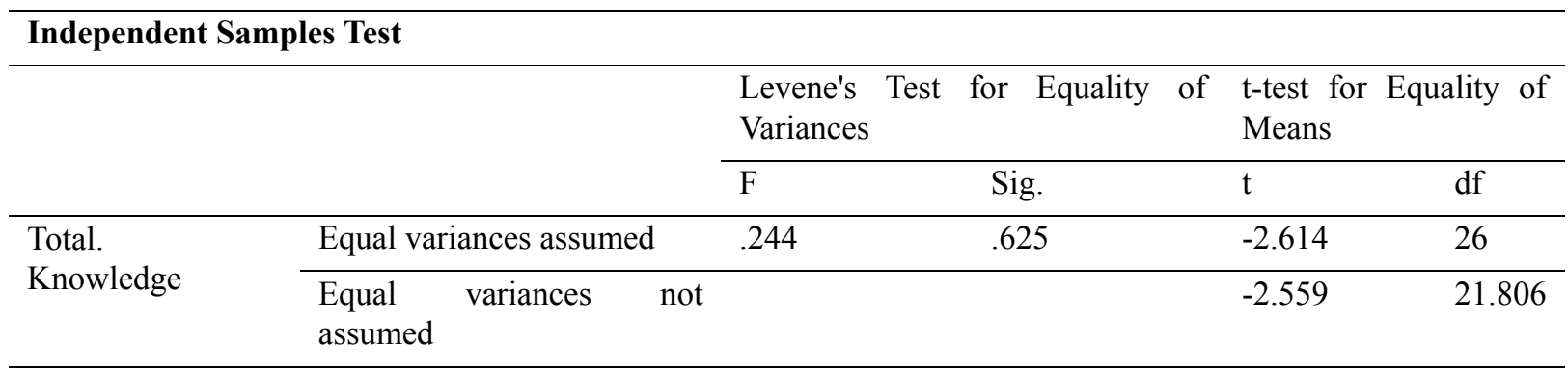

\section{Independent Samples Test}

\begin{tabular}{|c|c|c|c|c|}
\hline & & \multicolumn{3}{|c|}{ t-test for Equality of Means } \\
\hline & & Sig. (2-tailed) & Mean Difference & $\begin{array}{ll}\text { Std. } & \text { Error } \\
\text { Difference } & \end{array}$ \\
\hline \multirow[t]{2}{*}{ Total.Knowledge } & Equal variances assumed & .015 & -2.81250 & 1.07606 \\
\hline & Equal variances not assumed & .018 & -2.81250 & 1.09904 \\
\hline
\end{tabular}

\section{Independent Samples Test}

\begin{tabular}{llll}
\hline & & \multicolumn{2}{l}{ t-test for Equality of Means } \\
\cline { 3 - 4 } & & \multicolumn{2}{l}{$95 \%$ Confidence Interval of the Difference } \\
\cline { 2 - 4 } & & Lower & Upper \\
\hline Total.Knowledge & Equal variances assumed & -5.02437 & -.60063 \\
\cline { 2 - 4 } & Equal variances not assumed & -5.09294 & -.53206 \\
\hline
\end{tabular}

\section{Effect of Reason for Learning on Knowledge:}

\section{Descriptives}

\begin{tabular}{|c|c|c|c|c|c|}
\hline \multicolumn{6}{|l|}{ Mean. Attitude } \\
\hline \multirow[t]{2}{*}{$\mathrm{N}$} & \multirow[t]{2}{*}{ Mean } & \multirow[t]{2}{*}{ Std. Deviation } & \multirow[t]{2}{*}{ Std. Error } & $\begin{array}{l}\text { 95\% Confider } \\
\text { Mean }\end{array}$ & Interval for \\
\hline & & & & Lower Bound & $\begin{array}{l}\text { Upper } \\
\text { Bound }\end{array}$ \\
\hline
\end{tabular}




\begin{tabular}{lllllll}
\hline postgraduate & 11 & 3.3758 & .84867 & .25588 & 2.8056 & 3.9459 \\
\hline undergraduate & 10 & 3.3667 & 1.08560 & .34330 & 2.5901 & 4.1433 \\
\hline other & 7 & 2.4095 & .77021 & .29111 & 1.6972 & 3.1219 \\
\hline Total & 28 & 3.1310 & .98557 & .18626 & 2.7488 & 3.5131 \\
\hline
\end{tabular}

\begin{tabular}{lll}
\hline Descriptives & & \\
\hline Mean. Attitude & & \\
\hline & Minimum & Maximum \\
\hline postgraduate & 1.80 & 5.00 \\
\hline undergraduate & 1.53 & 5.00 \\
\hline other & 1.00 & 3.27 \\
\hline Total & 1.00 & 5.00 \\
\hline
\end{tabular}

\begin{tabular}{llllll}
\hline ANOVA & \multicolumn{1}{l}{} \\
\hline Mean. Attitude & \multicolumn{1}{l}{ Sum of Squares } & $\mathrm{df}$ & Mean Square & $\mathrm{F}$ & Sig. \\
\hline Between Groups & 4.858 & 2 & 2.429 & 2.842 & .077 \\
\hline Within Groups & 21.368 & 25 & .855 & & \\
\hline Total & 26.227 & 27 & & & \\
\hline
\end{tabular}

\section{Post-Hoc Tests}

\section{Multiple Comparisons}

Mean. Attitude

LSD

\begin{tabular}{|c|c|c|c|c|}
\hline $\begin{array}{l}\text { (I) reason for learning } \\
\text { English }\end{array}$ & $\begin{array}{l}\text { (J) reason for learning } \\
\text { English }\end{array}$ & $\begin{array}{l}\text { Mean Difference } \\
(\mathrm{I}-\mathrm{J})\end{array}$ & Std. Error & Sig. \\
\hline \multirow[t]{2}{*}{ postgraduate } & undergraduate & .00909 & .40395 & .982 \\
\hline & other & $.96623^{*}$ & .44700 & .040 \\
\hline \multirow[t]{2}{*}{ undergraduate } & postgraduate & -.00909 & .40395 & .982 \\
\hline & other & $.95714^{*}$ & .45561 & .046 \\
\hline \multirow[t]{2}{*}{ other } & postgraduate & $-.96623^{*}$ & .44700 & .040 \\
\hline & undergraduate & $-.95714^{*}$ & .45561 & .046 \\
\hline
\end{tabular}

*. The mean difference is significant at the 0.05 level.

\section{Multiple Comparisons}

\section{Mean. Attitude}

LSD

\begin{tabular}{llll}
\hline $\begin{array}{l}\text { (I) reason for learning } \\
\text { English }\end{array}$ & $\begin{array}{l}(\mathrm{J}) \text { reason for learning } \\
\text { English }\end{array}$ & \multicolumn{2}{l}{$95 \%$ Confidence Interval } \\
\cline { 3 - 4 } & undergraduate & Lower Bound & Upper Bound \\
\hline postgraduate & other &. .8229 & .8410 \\
\cline { 2 - 4 } & ong & .0456 & 1.8868 \\
\hline
\end{tabular}




\begin{tabular}{llll}
\hline undergraduate & postgraduate & -.8410 & .8229 \\
\cline { 2 - 4 } & other & .0188 & 1.8955 \\
\hline \multirow{2}{*}{ other } & postgraduate & -1.8868 & -.0456 \\
\cline { 2 - 4 } & undergraduate & -1.8955 & -.0188 \\
\hline
\end{tabular}

6. Predicting Knowledge (based on Attitude, Age, Gender, Reason):

\section{Variables Entered/Removed ${ }^{\mathrm{a}}$}

\begin{tabular}{llllll}
\hline Model & $\begin{array}{l}\text { Variables } \\
\text { Entered }\end{array}$ & $\begin{array}{l}\text { Variables } \\
\text { Removed }\end{array}$ & Method & & \\
\hline 1 & age & $\cdot$ & $\begin{array}{l}\text { Stepwise (Criteria: Probability-of-F-to-enter } \\
\text { Probability-of-F-to-remove }>=.100) .\end{array}$ & & \\
& & & .050,
\end{tabular}

a. Dependent Variable: Total.Knowledge

\begin{tabular}{|c|c|c|c|c|c|c|c|c|}
\hline \multicolumn{9}{|c|}{ Model Summary } \\
\hline \multirow{2}{*}{$\begin{array}{l}\text { Model } \\
1\end{array}$} & \multirow{2}{*}{$\begin{array}{l}\mathrm{R} \\
.456^{\mathrm{a}}\end{array}$} & \multirow{2}{*}{$\begin{array}{l}\text { R Square } \\
.208\end{array}$} & \multicolumn{2}{|c|}{$\begin{array}{l}\text { Adjusted } \\
\text { Square }\end{array}$} & $\mathrm{R}$ & \multicolumn{2}{|c|}{ Std. Error of the Estimate } & \\
\hline & & & \multicolumn{2}{|l|}{.178} & & \multicolumn{2}{|l|}{2.81778} & \\
\hline \multicolumn{9}{|c|}{ a. Predictors: (Constant), age } \\
\hline \multicolumn{9}{|c|}{ ANOVA $^{b}$} \\
\hline \multicolumn{2}{|l|}{ Model } & \multicolumn{2}{|c|}{ Sum of Squares } & $\mathrm{df}$ & & Mean Square & $\mathrm{F}$ & Sig. \\
\hline \multirow[t]{3}{*}{1} & Regression & 54.241 & & 1 & & 54.241 & 6.831 & $.015^{\mathrm{a}}$ \\
\hline & Residual & 206.438 & & 26 & & 7.940 & & \\
\hline & Total & 260.679 & & 27 & & & & \\
\hline
\end{tabular}

a. Predictors: (Constant), age

b. Dependent Variable: Total.Knowledge

\section{Coefficients $^{\mathbf{a}}$}

\begin{tabular}{|c|c|c|c|c|c|c|}
\hline \multicolumn{2}{|c|}{ Model } & \multicolumn{2}{|c|}{ Unstandardized Coefficients } & \multirow{2}{*}{$\begin{array}{l}\text { Standardized } \\
\text { Coefficients } \\
\text { Beta }\end{array}$} & \multirow[t]{2}{*}{$\mathrm{t}$} & \multirow[t]{2}{*}{ Sig. } \\
\hline & & $\mathrm{B}$ & Std. Error & & & \\
\hline \multirow[t]{2}{*}{1} & (Constant) & 2.188 & 1.773 & & 1.234 & .228 \\
\hline & age & 2.812 & 1.076 & .456 & 2.614 & .015 \\
\hline
\end{tabular}

a. Dependent Variable: Total.Knowledge

\begin{tabular}{lllllll}
\hline Excluded Variables $^{\mathbf{b}}$ & \multicolumn{2}{l}{} & \\
\hline Model & Beta In & $\mathrm{t}$ & Sig. & $\begin{array}{l}\text { Partial } \\
\text { Correlation }\end{array}$ & Collinearity Statistics \\
\cline { 3 - 7 } & & & & & Tolerance \\
\hline 1 & Mean. Attitude & $.327^{\mathrm{a}}$ & 1.866 & .074 & .350 & .906 \\
\cline { 2 - 7 } & gender & $-.243^{\mathrm{a}}$ & -1.371 & .182 & -.264 & .936
\end{tabular}

a. Predictors in the Model: (Constant), age

b. Dependent Variable: Total.Knowledge 


\section{Data Information}

\begin{tabular}{|c|c|c|c|c|c|c|c|c|}
\hline \multicolumn{9}{|c|}{ Variable Information } \\
\hline Variable & Position & Label & $\begin{array}{l}\text { Measurement } \\
\text { Level }\end{array}$ & Role & $\begin{array}{l}\text { Column } \\
\text { Width }\end{array}$ & Alignment & $\begin{array}{l}\text { Print } \\
\text { Format }\end{array}$ & $\begin{array}{l}\text { Write } \\
\text { Format }\end{array}$ \\
\hline age & 1 & $<$ none $>$ & Nominal & Input & 8 & Right & F8.2 & $\mathrm{F} 8.2$ \\
\hline gender & 2 & $<$ none $>$ & Nominal & Input & 8 & Right & F8.2 & F8.2 \\
\hline reason & 3 & reason for learning English & Nominal & Input & 8 & Right & F8.2 & F8.2 \\
\hline $\mathrm{k} 1$ & 4 & $\begin{array}{l}\text { At BBC Learning English there are } \\
\text { a topical multimedia content for } \\
\text { people all over the world who want } \\
\text { to speak English for }\end{array}$ & Scale & Input & 8 & Right & F8.2 & $\mathrm{F} 8.2$ \\
\hline k2 & 5 & $\begin{array}{l}\text { General and Business English has } \\
\text { many program such as }\end{array}$ & Scale & Input & 8 & Right & F8.2 & F8.2 \\
\hline k3 & 6 & $\begin{array}{l}\text { All programs and websites center at } \\
\text { BBC Learning English around }\end{array}$ & Scale & Input & 8 & Right & F8.2 & F8.2 \\
\hline k4 & 7 & $\begin{array}{l}\text { Learning English blog on } \mathrm{BBC} \\
\text { Learning English related to }\end{array}$ & Scale & Input & 8 & Right & F8.2 & $\mathrm{F} 8.2$ \\
\hline $\mathrm{k} 5$ & 8 & $\begin{array}{l}\text { "English at Work" is a new series of } \\
\text { programs on BBC Learning English } \\
\text { to help you learn some useful } \\
\text { business language which you could } \\
\text { use in }\end{array}$ & Scale & Input & 8 & Right & F8.2 & $\mathrm{F} 8.2$ \\
\hline k6 & 9 & $\begin{array}{l}\text { The "Quizzes program" on BBC } \\
\text { Learning English has many } \\
\text { questions on different topics, they } \\
\text { are: }\end{array}$ & Scale & Input & 8 & Right & F8.2 & $\mathrm{F} 8.2$ \\
\hline k7 & 10 & $\begin{array}{l}\text { There are many characters in "The } \\
\text { Flatmates program" on } \mathrm{BBC} \\
\text { Learning English, they are }\end{array}$ & Scale & Input & 8 & Right & F8.2 & F8.2 \\
\hline $\mathrm{k} 8$ & 11 & $\begin{array}{l}\text { On BBC Learning English, "Follow } \\
\text { sporting stories and learn English } \\
\text { along the way" is the idea of }\end{array}$ & Scale & Input & 8 & Right & F8.2 & $\mathrm{F} 8.2$ \\
\hline $\mathrm{k} 9$ & 12 & $\begin{array}{l}\text { On BBC Learning English, "Every } \\
\text { week we ask you a different } \\
\text { question. Hear what people in } \\
\text { London say" is the idea of }\end{array}$ & Scale & Input & 8 & Right & F8.2 & F8.2 \\
\hline $\mathrm{k} 10$ & 13 & $\begin{array}{l}\text { On BBC Learning English, "Tell us } \\
\text { what you think about this photo. } \\
\text { Each month throughout } 2012 \text { we'll } \\
\text { be focusing on a different colure" is } \\
\text { the idea of }\end{array}$ & Scale & Input & 8 & Right & F8.2 & $\mathrm{F} 8.2$ \\
\hline k11 & 14 & $\begin{array}{l}\text { Pronunciation tips from } \mathrm{BBC} \\
\text { Learning English has many program } \\
\text { such as }\end{array}$ & Scale & Input & 8 & Right & F8.2 & F8.2 \\
\hline at1 & 15 & $\begin{array}{l}\text { I like learning with e-resources on } \\
\text { BBC Learning English. }\end{array}$ & Scale & Input & 8 & Right & F8.2 & F8.2 \\
\hline at2 & 16 & $\begin{array}{l}\text { I like to access e-resources on } \mathrm{BBC} \\
\text { Learning English from anywhere. }\end{array}$ & Scale & Input & 8 & Right & F8.2 & F8.2 \\
\hline at3 & 17 & I feel that using the e-resources to & Scale & Input & 8 & Right & F8.2 & F8.2 \\
\hline
\end{tabular}




\begin{tabular}{|c|c|c|c|c|c|c|c|c|}
\hline & & $\begin{array}{l}\text { help me to get more progress in } \\
\text { learning English. }\end{array}$ & & & & & & \\
\hline at4 & 18 & $\begin{array}{l}\text { I prefer using the e-resources } \\
\text { because they are more available. }\end{array}$ & Scale & Input & 8 & Right & F8.2 & F8.2 \\
\hline at5 & 19 & $\begin{array}{l}\text { I dislike using e-resources on BBC } \\
\text { Learning English. }\end{array}$ & Scale & Input & 8 & Right & F8.2 & F8.2 \\
\hline at6 & 20 & $\begin{array}{l}\text { I prefer using an English book in my } \\
\text { school instead of using e-resources } \\
\text { on BBC Learning English. }\end{array}$ & Scale & Input & 8 & Right & F8.2 & F8.2 \\
\hline at7 & 21 & $\begin{array}{l}\text { I feel that using e-resources on BBC } \\
\text { Learning English help me to learn } \\
\text { independently. }\end{array}$ & Scale & Input & 8 & Right & F8.2 & F8.2 \\
\hline at8 & 22 & $\begin{array}{l}\text { I feel bored when I use e-resources } \\
\text { on BBC Learning English. }\end{array}$ & Scale & Input & 8 & Right & F8.2 & F8.2 \\
\hline at9 & 23 & $\begin{array}{l}\text { I do not trust the information in } \\
\text { e-resources on BBC Learning } \\
\text { English. }\end{array}$ & Scale & Input & 8 & Right & F8.2 & F8.2 \\
\hline at10 & 24 & $\begin{array}{l}\text { I feel that using e-resources on } \mathrm{BBC} \\
\text { Learning English made me } \\
\text { confused. }\end{array}$ & Scale & Input & 8 & Right & F8.2 & F8.2 \\
\hline at11 & 25 & $\begin{array}{l}\text { I feel that using e-resources on BBC } \\
\text { Learning English are helpful. }\end{array}$ & Scale & Input & 8 & Right & F8.2 & F8.2 \\
\hline at12 & 26 & $\begin{array}{l}\text { I feel that using e-resources on BBC } \\
\text { Learning English enhance the } \\
\text { learning process efficiently. }\end{array}$ & Scale & Input & 8 & Right & F8.2 & F8.2 \\
\hline at13 & 27 & $\begin{array}{l}\text { I find e-resources on BBC Learning } \\
\text { English hard to deal with. }\end{array}$ & Scale & Input & 8 & Right & F8.2 & F8.2 \\
\hline at14 & 28 & $\begin{array}{l}\text { It is difficult to find appropriate } \\
\text { materials for my level in e-resources } \\
\text { on BBC Learning English. }\end{array}$ & Scale & Input & 8 & Right & F8.2 & F8.2 \\
\hline at15 & 29 & $\begin{array}{l}\text { I feel that e-resources on } \mathrm{BBC} \\
\text { Learning English enrich my } \\
\text { knowledge of the English language. }\end{array}$ & Scale & Input & 8 & Right & F8.2 & F8.2 \\
\hline Total.Knowledge & 30 & Total knowledge & Scale & Input & 17 & Right & F8.2 & F8.2 \\
\hline Mean. Attitude & 31 & Mean attitude & Scale & Input & 15 & Right & F8.2 & F8.2 \\
\hline
\end{tabular}

\section{Copyrights}

Copyright for this article is retained by the author(s), with first publication rights granted to the journal.

This is an open-access article distributed under the terms and conditions of the Creative Commons Attribution license (http://creativecommons.org/licenses/by/4.0/). 